\title{
Samuel P. Huntington (1927-2008)
}

Jane S. Jaquette y Abraham F. Lowenthal ${ }^{*}$

Samuel Phillips Huntington, who passed away on December 24, 2008, was the most influential U.S. political scientist and one of the world's most prominent public intellectuals of the past fifty years.

Unlike his two early contemporaries on the Harvard University faculty, Henry Kissinger and Zbigniew Brzezinski, Huntington did not leave academia for the policy-making world. Except for two years (1977-78) in the Carter Administration's National Security Council staff (at Brzezinski's invitation), Huntington remained essentially a scholar. He occasionally offered advice directly to public officials, including to the U.S. government in the 1960s on how to build civic support in Vietnam, and to Brazil's military government in the 1970s on how to liberalize gradu- ally and open the way back toward civilian government. But Samuel Huntington's main contribution was as an analyst, writer and teacher, not as a policy maker or policy advisor.

During each of the last six decades, beginning with his classic The Soldier and the State in 1957, Huntington repeatedly framed the academic and sometimes the broader debate on an astounding variety of issues: civilmilitary relations; the political culture and institutions of the United States; the weaknesses of modernization theory; the sources and dynamics of the «third wave» of democratization; the likelihood of a post-Cold War "clash of civilizations»; the impact of Hispanic immigration on American identity and influence; and the central importance of political institutions as well as the

Jane S. Jaquette es Profesora Eméritita de política, Occidental College.

Abraham F. Lowenthal es Profesor de Relaciones Internacionales de la University of Southern California. Asimismo es Presidente Emérito y Senior Fellow del Pacific Council on International Policy, y non-resident Senior Fellow de la Brookings Institution. 
significance of deep culture and of personal leadership.

On each of these diverse topics, Huntington's arguments remain at the heart of scholarly, political and policy discourse. Some of his perceptive insights and theoretical frameworks continue to illuminate complex questions; others have been challenged and even discredited. But no one can deny the towering presence of Samuel Huntington: consistently able to define and attract attention to important questions; draw evidence from a broad knowledge of relevant theories and comparative data; couch his arguments in clear and often arresting prose; challenge conventional views; train numerous leading scholars and professionals; and direct research centers and notable journals. Huntington moved from subject to subject without tiresome repetition or the recourse to exclusionary jargon to which many social scientists succumb. His penchant for big topics, his capacity for comparative analysis, and his lucid prose made Samuel Huntington obligatory reading for three generations of students and scholars and for an increasingly broad range of others, in the United States and throughout the world.

Huntington wrote, co-authored, edited or co-edited nineteen volumes and numerous scholarly articles. A new edition (the fifteenth) of The Soldier and the State was published in August 2008. His most widely discussed work, The Clash of Civilizations and the Remaking of the World Order (1996) became a major best-seller worldwide, appear- ing in many editions and languages. His 1993 Foreign Affairs article «The Clash of Civilizations?» introducing his predictions that the post Cold War world would be less about ideological or economic conflict and more about civilizational rivalry, has been translated and debated on every continent save Antarctica.

\section{FIVE SEMINAL WORKS}

Time and space considerations require us to focus here on but five of Huntington's volumes: Political Order in Changing Societies (1968); American Politics: The Promise of Disharmony (1981); The Third Wave: Democratization in the Late Twentieth Century (1991); The Clash of Civilizations and the Remaking of the World Order (1996); and Who Are We? The Challenge to America's International Identity (2004), his final and in many ways least satisfactory book.

Political Order in Changing Societies was Huntington's most powerful, original and theoretical work, and his most enduringly influential in the academic literature. Wading into the strong current of optimistic accounts of modernization and of economic and political change both in Latin America and in the newly independent former colonial countries, Huntington challenged the prevailing assumptions and arguments. His opening paragraphs, starkly presenting his fundamental position, deserve quotation: 
The most important political distinction among countries concerns not their form of government but their degree of government. The differences between democracy and dictatorship are less than the differences between those countries whose politics embodies consensus, community, legitimacy, organization, effectiveness, stability, and those countries whose politics is deficient in those qualities. Communist totalitarian states and Western liberal states both belong generally in the category of effective rather than debile political systems. The United States, Great Britain, and the Soviet Union have different forms of government, but in all three systems the government governs... These governments command the loyalties of their citizens and thus have the capacity to tax resources, to conscript manpower, and to innovate and to execute policy. In all these characteristics, the political systems of the United States, Great Britain and the Soviet Union differ significantly from the governments which exist in many, if not most, of the modernizing countries of Asia, Africa, and Latin America.

Having unflinchingly characterized the violent and unstable politics that dominated most of the developing world, Huntington set out to analyze and explain such political decay and the requisites of political order; to explore why it had been so difficult for Western social scientists to recognize and deal with these issues; and to advance practical ideas about what could and should be done.

An astoundingly broad and eclectic range of sources, methods and data informs Political Order. In the first chapter alone, Huntington draws on citations from anthropology, economics, history, law, political science, public administration and sociology as well as from a contemporary novel. He cites such classic authors as Aristotle, Plato, Plutarch, Machiavelli, Hobbes, Gibbons, Burke, Tocqueville and Sarmiento. But he also draws on four unpublished doctoral dissertations and a Master's thesis; on numerous country and area study specialists on and from countries all over the world; and on more than forty major contemporary social scientists.

Huntington's fundamental thesisdeveloped and presented with an effective combination of analytic logic, historical evidence and comparative insight-was that rapid social change and the consequent mobilization of new groups into politics often outpaced the development of political institutions able to process their participation and demands. When the rates of social mobilization and the expansion of political participation are high and the levels of political organization and political institutionalization are low, the result is political instability and disorder.

Because of the history of the United States, American social scientists and policy makers tend to think, not about the creation of authority and the accumulation of power, but rather about limiting authority and dividing power. They concentrate, therefore, on assuring free and fair elections, without realizing that «elections to be meaningful presuppose a certain level of political 
organization... The problem is not to hold elections but to create organizations... Authority has to exist before it can be limited.»

Starting with these compelling observations, Huntington analyzed the prerequisites of authority and effective government at different levels of mobilization, participation, and institutional development. He systematically refuted various optimistic assumptions and hypotheses of the modernization literature about the process that, until Huntington's critique, had generally been conceived in teleological terms as "political development.» He substituted a theory based on the changing relationship between political participation and political institutionalization and applied his theory to traditional, modernizing and modern societies in many regions of the world. He developed general propositions that illuminated and explained many cases previously thought of as idiosyncratic or even inexplicable, cast doubt on the direction of change, and focused on the sources of authority and order.

Of particular utility was his original discussion of military intervention in politics, arguing that its important causes were not the social and organizational characteristics of the armed forces, but the political and institutional structure of the society. The reason military explanations do not explain military interventions, Huntington argued, is that military interventions are only one specific manifestation of a broader phenomenon: the politicization of so- cial forces and institutions.»Countries that have political armies also have political clergies, political universities, political bureaucracies, political labor unions, and political corporations... What makes such groups politicized is the absence of effective political institutions capable of mediating, refining, and moderating political action.»

In such situations, which Huntington terms «praetorian,» social forces confront each other nakedly. "No political institution, no corps of professional political leaders are recognized and accepted as the legitimate intermediaries to mediate group conflict. Equally important, no agreement exists among the groups as to the legitimate and authoritative methods for resolving conflicts.» In both Western constitutional democracies and communist dictatorships, there is general agreement on the means for allocating offices, distributing power, and resolving disputes, but this is not so in a praetorian society where «each group employs the means which reflect its peculiar nature and capabilities.»

Political Order in Changing Societies presents tightly reasoned and highly nuanced analysis for 461 pages, and includes too many important ideas to be summarized here. Of special interest, for example, is his discussion of the possibility of revolution in a deeply praetorian society:

In the normal polity the conservative is devoted to stability and the preservation of order, while the radical 
JAQueTTE Y LowenthaL • Samuel P. Huntington (1927-2008)

threatens these with abrupt and violent change. But what meaning do concepts of conservatism and radicalism have in a completely chaotic society where order must be created through a positive act of political will? In such a society who then is the radical? Who is the conservative? Is not the only true conservative the revolutionary?

But true revolution is difficult and rare, Huntington goes on to point out, and its results are not always positive or permanent. True reform, however, is even rarer, and in some ways even more difficult, he says in introducing Chapter 6, on «Reform and Political Change,» a brilliantly comparative, practical and constructive discussion of reform-mongering and the central importance of building civic organizations and political parties. Chapter 7 focuses sharply on political parties, and has not since been improved upon as a statement of the indispensable need for political organization as the foundation for political stability and the precondition of political liberty. "The vacuum of power and authority which exists in so many modernizing countries may be filled temporarily with charismatic leadership or by military force. But it can be filled permanently only by political organization... In the modernizing world he controls the future who organizes its politics.» These are still important truths.

American Politics: The Promise of Disharmony (1981) was in effect Huntington's response to the tumultuous events in the United States during the late 1960s. Characteristically, he sought to counter the polarized arguments about this period by putting it in historical perspective. He countered those on the left, who hoped the civil rights and anti-war movements and changes in mores and attitudes might add up to revolutionary change. But he also answered those on the right who feared that the radical claims and sometimes violent tactics of student rebels marked a serious rupture in American political culture. Huntington instead found important similarities between the 1960s and prior outbursts of «creedal passion.» The driving force behind these recurrent eruptions was not a revolutionary impulse, Huntington maintained, but a renewed public awareness of the gap between American ideals and American political realities. The struggles of the 1960s did not involve conflicts between "partisans of different principles, but a reaffirmation of traditional American ideals and values; they were a time of comparing practice to principle, of reality to ideal, of behavior to belief.» Sit-ins, boycotts and marches focused on Jim Crow and black disenfranchisement, «that area of American life where the gap between ideal and reality was most obvious and blatant.»

Huntington labeled the ideal the "American Creed," and defined it as a broad consensus on values that are "liberal, individualistic, democratic, [and] egalitarian,» and essentially "antigovernment and antiauthority in character.» Popular awareness of the 
gap between institutions and ideals usually remains latent in American politics. But at certain moments it can rise to the surface, challenging established institutions and existing practices, Huntington argues, as it did in the «Revolutionary era of the 1760 s and 1770 s, the Jacksonian age of the 1820 s and 1830s, and the Populist-Progressive years of the 1890 s and the 1900s.»

Huntington contrasted his argument with three paradigms that have been used to interpret American politics. The "progressive» approach emphasizes class relations and class conflict, finding the United States similar to Europe rather than exceptional. The "consensus» model, exemplified by Tocqueville and especially Louis Hartz, argues that the abundance of land and opportunities for social mobility explains why the United States lacked «both feudalism and socialism.» The "pluralist» interpretation describes US politics as a competition among interest groups. Each paradigm uses social structures and economic interests to explain American politics, Huntington noted, with the pluralist and class conflict theorists seeing perpetual competition over "grubby materialistic interests» while consensus theory «reduces it all to placid harmony and dullness.» Huntington thought that all three frameworks were too static, however, and that they missed the importance of political ideas in American politics. "America has been spared class conflicts in order to have moral convulsions," he wrote, because its social and political inequalities contrast with a moral environment committed to equality.

To Huntington, the American Creed was the bedrock of American national identity. Some countries, like China, have a «monism» of both ideology and nationality, and others, such as France and Italy, have ideological competition but a single nationality. "The United States, on the other hand, is composed, apart from the Indian tribes, not of nationalities but of ethnic groups.» These have not fully assimilated «into the culture and community of the white Anglo-Saxon Protestants» nor intermarried to create a new American «race,» but became American precisely by accepting "American political values, ideals and symbols.» If that were to change, «America» would no longer exist.

Periodically, however, the gap between American ideals and American practices goes from being denied, ignored, or cynically accepted to become the central issue. Complacency shifts to self-criticism. The gap between ideals and reality can also produce a politics prone to political distortions: belief in conspiracy theories, excessive government secrecy, or a tendency to put too much trust in individual politicians simply because they seem «sincere.» In addition to the civil rights movement, the domestic turmoil over the Vietnam war fit Huntington's theoretical framework. The contrast between periods of creedal passivity and creedal passion make periods of moral awakening seem apocryphal and violent, Huntington 
argued, with attacks on authority and calls for institutional change. As the United States became a more powerful global actor, its foreign policy (which is realist and therefore constrained in many of its goals and practices) was increasingly vulnerable to the charge that it was not consistent with American ideals.

To those who thought US policy should try to address this by reducing «the gap between other people's institutions and American values," Huntington cautioned that this is far from easy for four reasons. First, «to intrude from outside is imperialism or colonialism.» Second, the task is «simply beyond American knowledge, skill, and resources.» Third, such interventions «needlessly antagonize» other governments. Fourth, doing so «poses dangers to the operation of democratic government within the United States.» In retrospect, as one reflects on a series of unfortunate US involvements abroad, these concerns seem remarkable prescient and wise. They foreshadow Huntingon's own opposition to the Iraq invasion in 2003.

Huntington acknowledged that strong arguments could be made in favor of US international activism: US intervention might be justified if the institutions of another country "pose a direct threat» to the United States, or such intervention is supported by the population of another country or occurs to promote universally-held values. Or, it could be argued that the world is becoming so interdependent that it can- not contain competing systems without danger to the survival of liberal values. Choosing between these arguments for and against U.S. intervention abroad was not a matter of first principle for Huntington but of carefully balancing benefits and costs, potential gains and risks, with a bias toward prudence.

The charge from the 1960s that most nettled Huntington was that the United States, and US foreign policy in particular, was guilty of hypocrisy. He countered that those who support leftist movements are not necessarily supporting individual rights and freedoms because «the suppression of liberty in right-wing dictatorships is almost always less pervasive than it is in left wing totalitarian ones.» Contrary to both the «realists» and the «moralists,» Huntington declared that the contradiction arising from America's role in the world «is not primarily that of power and self-interest versus liberty and morality...but between enhancing liberty at home by curbing the power of the American government and enhancing liberty abroad by expanding that power.» Managing this tension is not easy, but is important.

Huntington concludes that the 1960s left the United States "with a more equitable society» and «a more open politics,» but also with «a more cynical public and a less authoritative and effective government; in other words, participation had increased, but institutionalization had weakened. Huntington ultimately put his faith, however, in the American Creed: «Crit- 
ics say that America is a lie because its reality falls so far short of its ideals. They are wrong. America is not a lie; it is a disappointment. But it can be a disappointment only because it is also a hope.»

Ten years later, in 1991, Huntington published The Third Wave: Democratization in the Late Twentieth Century. Impressed by the advances toward democratic governance in thirty countries in less than twenty years, Huntington underlined that democracy is not only "good in itself,» but also has "positive consequences for individual freedom, domestic stability, international peace, and the United States of America.»

The Third Wave begins with an account of a military coup-the 1974 overthrow of the Portuguese dictator, Marcello Caetano-that «implausibly and unwittingly» began a trend toward democratization, first in Southern Europe, then in Latin America and Eastern Europe, and eventually in several countries in Asia and Africa. The events that led to democracy in Portugal set off a series of transitions from authoritarianism that Huntington called the "Third Wave,» a label that stuck, like so many of Huntington's pithy phrases. Offering a post hoc analysis of the events and actions that might explain the surprising turn, Huntington concluded that "no single factor is sufficient" to explain why democracy developed «in all countries or in a single country,» and that "no single factor' is necessary to its development in all countries. Economic growth is critical, to produce a more highly educated public and a larger middle class, which may facilitate a civic culture of trust and a demand for institutional competence, but these do not automatically lead to democratic transitions.

External factors were important in reinforcing the Third Wave, Huntington argued. Increasing US support for democratic governments under the Carter and eventually the Reagan administrations and the impact of the Second Vatican Council (1962-65) made a difference in Southern Europe and Latin America, while the Helsinki Process and the role of the European Community helped promote transitions from authoritarianism in Eastern and Central Europe. But, Huntington insisted, external forces can only help push forward or retard democratization processes that are occurring within countries. Local leadership is critical. The third wave would not have been as successful had the international environment been less favorable, but «a democratic regime is installed not by trends but by people....Political leaders and publics have to act.»

Huntington's historical perspective led him to caution that the Third Wave might be reversible, as earlier periods of democratization (from 1828 to 1926 and 1943 to 1962) had been followed by «reverse waves» of authoritarian or even totalitarian rule. Democratization could shift into reverse under several conditions: if democracies showed a «sustained inability to provide welfare, prosperity, equity, justice, domestic 
order, or internal security»; or if there were a general economic collapse, on the order of the Great Depression. If an authoritarian government proved itself better able to address problems of security or economic growth or "greatly expanded its power,» a «snowballing effect» might occur, fueling the rise of «authoritarian nationalism.»

Countries that had adopted democracy but lacked the economic and prerequisites needed to sustain it were especially vulnerable. Anticipating democratic «disenchantment," Huntington predicted that «as authoritarian failures fade, irritation with democratic failures is likely to increase.» Several types of authoritarianism might emerge in such a reverse wave, from old fashioned oligarchic authoritarianism to preserve the wealth and power of the elites, to populist dictatorships, to authoritarian regimes based on religious fundamentalism or ethnic communalism. Consolidation would depend on whether the new regimes maintained their legitimacy, suggesting a series of problems that the newly established regimes would have to recognize and confront. These ranged from how the transitions were carried out; whether anti-democratic officials and leaders can be "weeded out» or marginalized; managing the role of the military; and the tendency, once democratic governance becomes the "norm,» toward an overdependence on performance measures. Huntington then turned to the problem of how to deal with those who were torturers under the authori- tarian regimes, concluding that «the least unsatisfactory course may be: do not prosecute, do not punish, do not forgive, and, above all, do not forget," advice consistent with the combination of amnesties and truth commissions that were widely adopted in several countries during the 1990s.

In the preface to The Third Wave, Huntington says that in his earlier books he tried to «develop generalizations or theories about the relations between key variables, such as political power and military professionalism, political participation and political institutionalization, and political ideals and political behavior.» In The Third Wave, however, he would limit his analysis to "a discrete class of events.» He continued to reflect on the role of leadership and institutions, but also introduced culture as an important variable. Citing George Kennan's view that modern democracies emerged in a Northern European cultural setting and may not be «the natural form of rule for peoples outside those narrow perimeters," Huntington proposes that the «Western culture thesis» has «immediate implications for democratization in the Balkans and the Soviet Union,» where Orthodox and Islamic religious beliefs are remain dominant. Lacking the «Western experiences with feudalism, the Renaissance, the Reformation, the Enlightenment, the French Revolution, and liberalism,» Huntington predicts that these countries will face great difficulties in adopting democratic institutions and that democ- 
ratization will be least likely to succeed in countries with cultural traditions that are hostile to democracy, notably Confucianism and Islam.

Culture is at the very heart of Huntington's next book, The Clash of Civilizations and the Remaking of World Order (1996). First advanced in 1993 in Foreign Affairs, Huntington's central thesis is that the world, no longer divided into a bipolar confrontation between two ideologies and two economic systems, is becoming a multipolar world of blocs. These would not be economic blocs as many were then predicting, however, but rather competing «civilizations.» Huntington's thesis was originally greeted with considerable skepticism by scholars, but after the events of September 11, 2001, his article and book received new attention, and Huntington was hailed, especially by the media and pundits, as prescient.

In making his case, Huntington took as his starting point two assertions made by many critics of realism: that the nation state was in decline and that the international system was on the verge of an historical shift. But, unlike them, Huntington did not see this shift as the harbinger of a new era of peace nor did he see a decisive role for transnational organizations or international institutions. States might be in decline, but conflict in the international system would continue, driven by clashes of «civilizations.» The realist understanding of international politics would remain relevant, therefore, as a necessary guide to prediction and policy.
The Clash of Civilizations opens with description of the two thousand people who demonstrated in Sarajevo in 1994, "waving the flags of Saudi Arabia and Turkey,» which showed, Huntington says, that they identified themselves with their "real friends," their fellow Muslims. That same year, 70,000 people marched in the streets of Los Angeles, «beneath a sea of Mexican flags.» Huntington saw these bits of evidence as support for his thesis that cultural identity is what is "most meaningful to people» in the post-Cold War world. However, this development was far from benign, for peoples «seeking identity and reinventing ethnicity» need «enemies.» Therefore, the emerging multipolar, multicultural world will not be a world of peace, as «euphoric» idealists were predicting, but one in which the growing awareness of cultural identities and new sources of economic and military power would mix with old anti-colonial and anti-imperialist resentments to produce competition and conflict. The relative decline of US power and the cultural hostility to democracy of the most rapidly rising civilizations presents a threat to US interests that must be recognized and managed.

Adapting Henry Kissinger's prediction that the $21^{\text {st }}$ century would "contain at least six major powers-the United States, Europe, China, Japan, Russia and probably India,» Huntington observed that these countries represented five different civilizations. Those who think of the post-Cold War in 
terms of rich and poor, East and West, or North and South are missing the most important trend, he maintained: the emergence of a world of competing civilizations. He identified them, in addition to the West, as «Islamic, Sinic, Hindu, Orthodox. Buddhist, Japanese, Latin American, and African,» adding Islam because countries within this cultural group were experiencing rapid demographic growth and several controlled important oil resources.

Civilizations are «totalities,» Huntington asserts, distinguished by «blood, language, religion, and way of life,» values people are willing to fight and die for. Ethnic conflicts and failed states are not evidence that the world is falling into chaos, Huntington maintains. The world does not lack order because «cultural assertion» is actually a force for integration. Nation states will continue to play important roles, but their «interests, associations and conflicts» will increasingly be shaped by «cultural and civilizational factors.» However, Huntington argues, the «balance of power» among civilizations is shifting. As the West is losing relative influence, "Asian civilizations are expanding their economic, military and political strengths; Islam is exploding demographically... and non-Western civilizations generally are reaffirming the value of their own culture.» The world is increasingly divided between «a Western one» and a «non-Western many,» between the «West and the rest.»

To support his case, Huntington assembles several different arguments.
We have not reached the "end of history» because we are not moving toward "convergence» on a set of universal values or institutions. Those who think so are confusing modernization with Westernization. Some more «instrumental» cultures, like those of Japan and India, "moved earlier and more easily into modernization,» while Confucian and Islamic societies, with more "consummatory» values, have lagged behind. This does not mean that Confucian and Islamic societies will be unable to modernize, but it does mean that they are likely to modernize in ways that are hostile to the West.

Because identity politics defines itself against those it excludes, and because cultural differences, once clearly defined and fought for, are much more difficult to compromise about than economic differences, future conflicts are likely to be violent. Countries with populations divided between two or more civilizations are «torn» countries, likely to experience deep internal divisions. Russia is an example; despite its long term relationship to Europe, «seven of eight ...distinctive features of Western civilization-religion, languages, separation of church and state, rule of law, social pluralism, representative bodies, individualism-[are] almost totally absent from the Russian experience.» If Russia became Western, Orthodox civilization would «cease to exist.» Turkey and Mexico are also examples of «torn» countries that remain culturally schizophrenic and therefore potentially unstable. 
In what Huntington terms an ironic twist, modernization has brought about a resurgence of religion. "People do not live by reason alone. They cannot calculate and act rationally in pursuit of their self interest until they define their self. Interest politics presupposes identity.... For people facing the need to determine Who am I? Where do I belong? religion provides compelling answers.» But this trend is also worrisome, as the revival of non-Western religions is "the most powerful manifestation of anti-Westernism in non-Western societies.»

Huntington analyzes the ways in which civilizational politics are becoming evident in the international system. Many of his examples reinforce his prediction that a Confucian-Islamic alliance is likely to form against the West. Asian and Muslim countries have been most intent on developing nuclear weapons, and the «buckle» of the arms connection links "China and North Korea on the one hand, and Pakistan and Iran on the other.» As he argued in The Third Wave, Huntington fears that cultural factors will undermine democracy in Russia and the Orthodox republics and thinks the prospects for democracy in the Muslim republics are "weak.» He wryly observes that the West is facing a new "democratic paradox.» In the past, United States felt it had to support authoritarian dictators to defend capitalism and democracy against the Soviet challenge. Now the West has to decide whether to support a secular, Western-oriented "tyrant" or continue to push for democracy, knowing that democratic elections in Muslim countries are likely to produce Islamic leaders hostile to the West. The response to this has been an unfortunate weakening of Western support for democracy as the Third Wave ebbs.

Avoiding war requires that "world leaders accept and cooperate to maintain the multicivilizational character of global politics,» Huntington counsels, but he also urges that Westerners accept their civilization as «unique» and «nonuniversal,» and unite "to renew and preserve it against challenges from non-Western societies.» Diaspora populations will make this increasingly difficult, Huntington predicts. He warns that the futures of the United States and the West depend on «rejecting the siren calls of multiculturalism» domestically, and internationally, on resisting the «elusive and illusory calls to identify the United States with Asia.» Core states will need to "refrain from intervening in conflicts in other civilizations» and be ready to negotiate with each other so that wars along «fault lines» do not escalate. The principal international institutions created after WWII reflect Western «interests, values, and practices,» and the West must accept reforms that recognize the interests of other core states, for example, by expanding the membership of the Security Council.

Huntington's conclusion draws on both his realism and his cultural analysis. It is possible to find ways to mitigate the coming conflicts, he proposes, because, in a world of civilizations, all those who have a stake 
in civilization will oppose violence. Drawing on James Kurth's observation that the "real clash" in the United States in the 1960s was between «the multiculturalists» and «the defenders of Western civilization,» Huntington suggests a parallel. The "real clash» in the coming world will be the clash «between Civilization and barbarism,» he argues. Therefore, the leaders of the world's «great civilizations, with their rich accomplishments in religion, art, literature, philosophy, science, technology, morality and compassion,» must seek common ground: they must «hang together, or hang separately.» Civilizational conflict is now the greatest threat to world peace, but «an international order based on civilizations is the surest safeguard against world war.»

In his final book, Who Are We? The Challenges to America's National Identity (2004), Huntington once more identified important questions, marshaled provocative data and arguments and stimulated wide discussion, but this time his contribution was more problematic.

Who Are We? explores what qualities make the United States distinct and attractive, and thus comprise America's identity, and asks whether and how these qualities can be preserved in new historical circumstances very different from those in which U.S. identity was originally forged. For three centuries, Huntington argues, the United States demonstrated an exceptional capacity to incorporate people of diverse backgrounds and win their allegiance to a core set of political values, institutions and practices that have been central to America's unity, power, prosperity and international leadership. Huntington succinctly analyzed when and how America's core values and cultural identity emerged, and how these were reinforced over its history. But historically all societies have faced threats to their distinct qualities, Huntington reminds us. He asks whether U.S. identity today is still strong enough to withstand the loss of major external challenges; the emergence of multiculturalism; the erosion of national loyalty by intellectual, political and business elites who are increasingly engaged in transnational and subnational communities; and the growth of a very large immigrant population from neighboring Mexico, with special characteristics that might cause greater resistance to assimilation and incorporation than had marked previous waves of immigration.

The sheer size of the flow of Mexican immigrants, Huntington suggested, raised potential problems for their assimilation into U.S. society. These problems could be exacerbated by the comparatively low educational level of Mexican immigrants; their relatively slow rates of political naturalization and socioeconomic advance; and the understandable resentment by the host population of the costs of incorporating large numbers of poor and uneducated Mexican immigrants into already over-burdened educational and socialwelfare systems. These concerns are not fairly dismissed as racist, as some of 
Huntington's detractors claimed; they need to be addressed as high-priority issues for U.S. public policy.

Huntington did not contribute positively to this consideration, however. Instead, he leapt from a cogent discussion of the unquestionably special nature of Mexican immigration to a parade of disturbing scenarios, jumping at several turns from considering a remote prospect for societal bifurcation to describing what he seemed to be projecting as an imminent threat. Huntington's correct statements that much of the United States was once part of Mexico, and that some Mexican Americans argue that the time of reconquista has arrived, gives way to an unwarranted projection that there could be a "consolidation of the Mexican-dominant areas into an autonomous, culturally and linguistically distinct, economically self-reliant bloc within the United States,» and even a «move to reunite these territories with Mexico.»

Similarly, Huntington emphasized worrisome data on educational and economic lags by Mexican immigrants while ignoring considerable contrary data showing progress on both fronts. Citing bits of anecdotal evidence that Mexican immigrants reject American identity, Huntington asserted that "as their numbers increase, Mexican Americans feel increasingly comfortable with their own culture, and often contemptuous of American culture.» But he disregarded extensive survey data showing that Mexican immigrants actually admire the rule of law and rewards for hard work so often lacking in Mexico. Far from rejecting the values of the United States, Mexican Americans are actually more likely than non-Hispanic whites to embrace core American tenets of individualism and patriotism. Huntington worried that Mexican immigrants could easily be mobilized to support Mexican policies against the interests of the United States. But available data show that to the modest extent that U.S. Latino communities affect U.S. foreign policy, their main impact has been to support and advance mainstream U.S. foreign policy goals: to strengthen democracy and promote international trade and investment.

Huntington's most widely-discussed conclusion in Who Are We? was that «the continuation of high levels of Mexican and Hispanic immigration plus the low rates of assimilation into American society and culture could eventually change America into a country of two languages, two cultures and two peoples.» Only gross exaggeration of probability at various points in the argument and consistent dismissal of contrary evidence could have led Huntington to this disturbing conclusion. In the end, therefore, Huntington's final volume fostered distracting polemics more than constructive dialogue about real policy challenges that the United States must face.

What caused Huntington in his 70s to turn from careful and dispassionate analysis to such exaggeration and po- 
lemic? As if to preempt this question, Huntington writes in his Foreword that his book is shaped by his own dual identities «as a patriot and a scholar,» and admits that the "motives of patriotism and of scholarship may conflict.» He warns readers that his «selection and presentation of evidence may well be influenced by a patriotic desire to find meaning and virtue in America's past and in its possible future.» Huntington was clearly aware of and struggling with a tension between these competing imperatives, but was unable to resolve them convincingly. Interestingly, in The Politics of Disharmony he had recognized that «the broader and longer-term impact of the Latin immigration of the 1950s, 1960s and 1970s could reinforce the central role of the American Creed both as a way of legitimizing claims to political, economic, and social equality and also as the indispensable element in defining national identity.» He speculated then that "at some point, traditional American ideals [might] lose their appeal,» but he expressed doubt that this would happen in the twentieth century. Whether what made Huntington more concerned about this possibility in the $21^{\text {st }}$ century arose mainly from changes in American society or rather within Huntington's psyche is a matter for conjecture.
Assessing SAMuel

\section{HuNTINGTON'S CONTRIBUTION}

From the very start of his career to its end, Huntington's work was controversial. Huntington was often denounced, sometimes for actual or imputed policy positions, and sometimes for the policy positions others took invoking his arguments, but almost always on ideological grounds.

Much of the controversy centered on his alleged bias toward authoritarianism. This was the initial attack of colleagues at Harvard and others on The Soldier and the State, in which Huntington contrasted the U.S. military academy at West Point, with an adjacent civilian community, Highland Falls, describing West Point as «ordered serenity» and «a bit of Sparta in the midst of Babylon.» It was also the fundamental critique some offered of Political Order in Changing Societies, with its provocative opening paragraphs and consistent concern with authority and order. That Huntington could see and advocate the virtues, in developing countries, of one party dominant systems, modernizing military regimes and even Leninist approaches made his work anathema to many, while his strong emphasis on order as a prerequisite to liberty provoked comparisons to Hobbes, not intended as complimentary. Nor did his view that it is actually easier to be a revolutionary than a reformer, but that reform is needed, make him popular or influential among those, in Latin America and elsewhere, who thought revolutionary change was necessary. 
In fairness, however, Huntington was not calling for militarism or military rule in Soldier and the State; his argument, on the contrary, was for a professional military institution with conservative and realist values to protect a liberal society, which would require institutionalizing "objective» and «subjective» civilian control of the armed forces. And his argument in $\mathrm{PO}_{\mathrm{O}}$ litical Order was certainly not in favor of dictatorial regimes but rather for the crucial importance of constructing authority and establishing civic order as a necessary first step toward making possible the conditions of liberty. Those who have lived or worked in «praetorian» societies, where social mobilization and rising claims for participation greatly exceed the capacity of political institutions to process expanding demands, appreciate Huntington's central argument, which has not lost its cogency despite the dramatic changes that have taken place in the forty years since he wrote. In many nations, including Iraq, Haiti and Afghanistan, but also several countries (or regions within countries) in Latin America and in Africa, it is clear that a minimal level of state capacity can neither be taken for granted nor easily achieved, and that building this capacity is the first priority.

The Third Wave demonstrates Huntington's normative preference for effective democratic governance, including the limits on power that are needed once authority has been constructed. But it is consistent with Politi- cal Order in identifying both economic development and effective political institutions as critical to democratic success. It also introduces a new theme, not emphasized in Political Order, that would become increasingly dominant in Huntington's writing - the importance of culture and the need to defend Western values. Even before he published his article on the clash of civilizations in 1993, Huntington had begun to differentiate the «institutionalization» that occurs in countries of the West from potentially competitive patterns of modernization and institutionalization occurring within other cultural traditions, such as China's economic success and the political order promised by radical Islam.

To reread Huntington's work is to become immersed once again in the difficult and often polarizing debates over US domestic policies and its international role that have occurred over the last forty years. To those, Huntington brought a command of comparative politics that was unmatched in its global scope and its eye for telling examples. He brought superb analytical and writing skills to the task of clarifying the major issues and drawing out their policy implications. Huntington took on the scholarly fads of the day, upending modernization theory in Political Order in Changing Societies and challenging the polarized interpretations of the 1960s in The Promise of Disharmony. Clash of Civilizations offered an alternative to both the optimism of Francis Fukuyama's 
«End of History» and the pessimism of Robert Kaplan's "Coming Anarchy,» and it is a measure of his stature that both these scholars, and many others, count themselves among his admirers. In all cases, his style was to surround his opponent's arguments with his own, eventually depriving them of oxygen, rather than engaging in frontal or ad hominem attacks. He was a brilliant advocate of his views, but not a flashy polemicist.

There are issues one wishes Huntington had explored more fully and contradictions one wishes he had addressed. Huntington recognized the critical importance both of economic growth and social equity, but he did not much discuss the institutions and policies necessary to achieve them nor the effect of US insistence (from the early 1980 s to the present) on promarket policies that arguably widened income inequalities and weakened state capacity. Development and welfare are elements of democratic performance to which he attached less importance than to cultural habits or political choices in predicting the staying power of democracies. Huntington's concern that the West unite to preserve the values of liberalism did not address the conflict between the libertarian elements of the American Creed and the social democratic values shared by much of «the rest of the West.» By making "core countries» the chief actors in the world he imagines in Clash of Civilizations, Huntington reasserted the realist paradigm of great power politics too unconditionally, taking inadequate account of globalization, transnational organizations, and the rise of civil society and their relation to democratic sustainability.

Yet unlike many contemporary theorists of international relations (and policy makers intent on using US «unipolar» power to further democracy), Huntington was a consistent realist, aware of Machiavelli's insight that human actions have unintended consequences, and knowing that actions taken on high moral grounds can have high moral costs. He did not foresee an end to the ethical and practical dilemmas, nor to the dangers, but also the promise, of politics. His commitment to clear and balanced thinking and to prudent action, and his willingness to challenge the clichés of the left and the right, will be sorely missed.

\section{A FINAL PERSONAL COMMENT BY Abe Lowenthal}

I was one of Huntington's doctoral students, assisted in his undergraduate course, worked closely with him on the Commission on U.S.-Latin American relations and traveled with Sam on what was for both of us a memorable first trip to Cuba in 1975.

Sam Huntington was unassuming and even diffident- except when his ideas were directly challenged. Although a master craftsman of expository written prose, Huntington was not an exceptional public speaker, and was 
unintimidating in the classroom and in examinations. People who knew him first through his robust and forceful writings were often surprised by his personal demeanor. What I most clearly remember about Sam was the alert and somewhat skeptical expression on his face as he listened to colleagues or students, and the shy smile of assent as he acknowledged a good point.

Huntington clearly loved teaching and wanted students to succeed; he was glad to offer good advice, solicited or not. He was quick to recognize and encourage new talent. He devoted the longest footnote in Political Order in Changing Societies to an unpublished graduate student paper of mine and put my first published essay on the syllabus for his undergraduate lecture coursevivid examples of how he nurtured those at the start of new careers.

Two vignettes from our Cuba trip illustrate Huntington's acuity. When we met with Blas Roca, the drafter of the new Cuban constitution adopted under Fidel Castro, Huntington turned to Roca, acknowledged that he had never previously been in Cuba nor traveled much in Latin America but allowed that he had read many constitutions. He then offered the observation that the new constitution provided a number of checks on the power of government, but not on the power of the Communist Party, "which is where real power probably resides.» Roca, taken aback, agreed!
The next day, Cuban officials from Prensa Latina (a mixture of press agency and intelligence service) told us with enthusiasm about the novel and progressive approach of Peru's «Revolutionary Government of the Armed Forces» under General Juan Velasco Alvarado, with its goal of establishing a «social democracy of full participation.» Huntington noted that what the Cubans were telling us with such evident conviction could not actually be true because it contradicted the essential organizational principles of a military institution. Scores of articles and books were written about «The Peruvian Experiment;» Huntington's quip caught one of the most important points in an instant.

Afflicted with diabetes from age 20, Sam Huntington lived with multiple daily reminders of his frail health. $\mathrm{He}$ sometimes experienced frightening episodes, once in my presence. He overcame these serious problems by applying to his daily life the kind of quiet but effective discipline that characterized his scholarship. He deeply understood life's promise and its limits. He recognized man's capacity both for community and for selfishness, the human qualities, as Reinhold Niebuhr emphasized, that make democracy both possible and necessary. Profound awareness of both these qualities shaped Samuel P. Huntington's scholarship and undergirds his enduring contribution. 